\title{
POLA SEBARAN DAN INDEKS EKOLOGI TERIPANG DI PERAIRAN ARMY DOCK DESA PANDANGA KABUPATEN PULAU MOROTAI
}

\section{DISTRIBUTION PATTERNS AND CIVIL INDEX INDEX IN ARMY DOCK WATERS, PANDANGA VILLAGE, MOROTAI ISLAND}

\author{
Nurafni ${ }^{1 *}$, Sandra Hi Muhammad ${ }^{1}$, Nurilfa Sari Kurung ${ }^{1}$ \\ 1Program Studi IImu Kelautan, Fakultas Perikanan dan IImu Kelautan, Universitas Pasifik Morotai, Indonesia \\ "Korespondensi: nurafni1710@gmail.com (Nurafni) \\ Diterima 20 Februari 2020 - Disetujui 25 Maret 2020
}

\begin{abstract}
ABSTRAK. Teripang atau yang lebih dikenal dengan timun laut merupakan salah satu organisme dari filum echinodermata kelas Holothuroidea. Teripang (Holothuroidea) dapat di temukan atau dijumpai di seluruh perairan pantai mulai dari daerah pasang surut yang dangkal sampai perairan yang lebih dalam. Tujuan penelitian ini adalah untuk mengetahui Pola Sebaran dan Indeks Ekologi Teripang di perairan Desa Pandanga Kabupaten Pulau Morotai.Penelitian ini dilakukan pada bulan Oktober sampai November 2019 dengan menggunakan Metode Transek Kuadrat. Dimulai dengan pengambilan data teripang di Perairan Army Dock Desa Pandanga Kecamatan Morotai Selatan Kabupaten Pulau Morotai.Data yang diperoleh kemudian dianalisis menggunakan formula pola distribusi internal dan indeks ekologi keanekaragaman jenis, indeks dominasi, indeks kemerataan). Hasil analisis menunjukkan bahwa nilai keanekaragam stasiun I sampai III (0,68-0,90), kemerataan $0.618-0,985$ dan dominasi $0,69-0,564$. Penyebaran teripang pada semua stasiun penelitian menunjukkan pola penyebaran bersifat mengelompok dengan nilai $>1$.
\end{abstract}

KATA KUNCI: Sebaran, indeks ekologi, pola sebaran, teripang, Morotai

ABSTRACT. Sea cucumbers or better known as sea cucumbers, are one of the organisms of the holothuroidea echinoderm phylum. Sea cucumbers (Holothuroidea) can be found or found in all coastal waters ranging from shallow tidal areas to deeper waters. The aims to of this study was to determine the distribution pattern and sea cucumber index in the waters of Pandanga Village, Morotai Island Regency. This research was conducted in October to November 2019 using the Quadrat Transect Method. Starting with sea cucumber data collection in the Army Dock Waters of Pandanga Village, South Morotai Subdistrict, Morotai Island Regency. The data obtained were then analyzed using the formula of internal distribution patterns and species diversity ecology index, dominance index, evenness index). The analysis showed that the diversity values of stations I to III (0.680.90), evenness from 0.618 to 0.985 and dominance from 0.69 to 0.564 . Sea cucumber distribution at all research stations shows the distribution pattern is clustered with value $>1$.

KEYWORDS: Distribution, ecological index, distribution patterns, sea cucumbers, Morotai

\section{Pendahuluan}

Teripang (Holothuroidea) atau lebih dikenal dengan nama timun laut merupakan salah satu organisme makrozoobenthos yang dapat ditemukan hampir diseluruh perairan dangkal sampai perairan yang dalam. Habitat hewan ini pada zona intertidal sampai kedalaman 20 meter (Aziz, 1997). Teripang berjumlah 350 jenis yang tersebar di perairan indonesia salah satunya di perairan Pulau Morotai. Pulau Morotai merupakan wilayah paling utara di Kawasan Timur Indonesia (KTI) yang termasuk bagian dari Provinsi Maluku Utara. Pulau morotai merupakan pulau terluar yang berbatasan langsung dengan negara tetangga (Filipina) dan memiliki fungsi strategis. Kabupaten Pulau Morotai dikelilingi 33 Pulau kecil yang memiliki potensi sumberdaya perikanan dan pariwisata yang dapat dimanfaatkan sebagai kawasan wisata maupun sejarah salah satu tempat wisata yang cukup dikenal 
adalah Army Dock. Perairan Army dock memiliki potensi keanekaragaman hayati seperti terumbu karang, lamun dan asosiasi biota salah satunya teripang. Sementara data dan informasi mengenai pootensi sumberdaya teripang masih sangat minim sehingga perlu dilakukan penelitian tentang indeks ekologi dan pola sebaran teripang yang tersebar di tempat wisata Army Dock.

\section{Bahan dan Metode}

Penelitian ini dilaksanakan pada bulan Oktober sampai Desember 2019 di perairan Army Dock Desa Pandanga Kabupaten Pulau Morotai. Lokasi penelitian dapat dilihat pada Gambar 1.

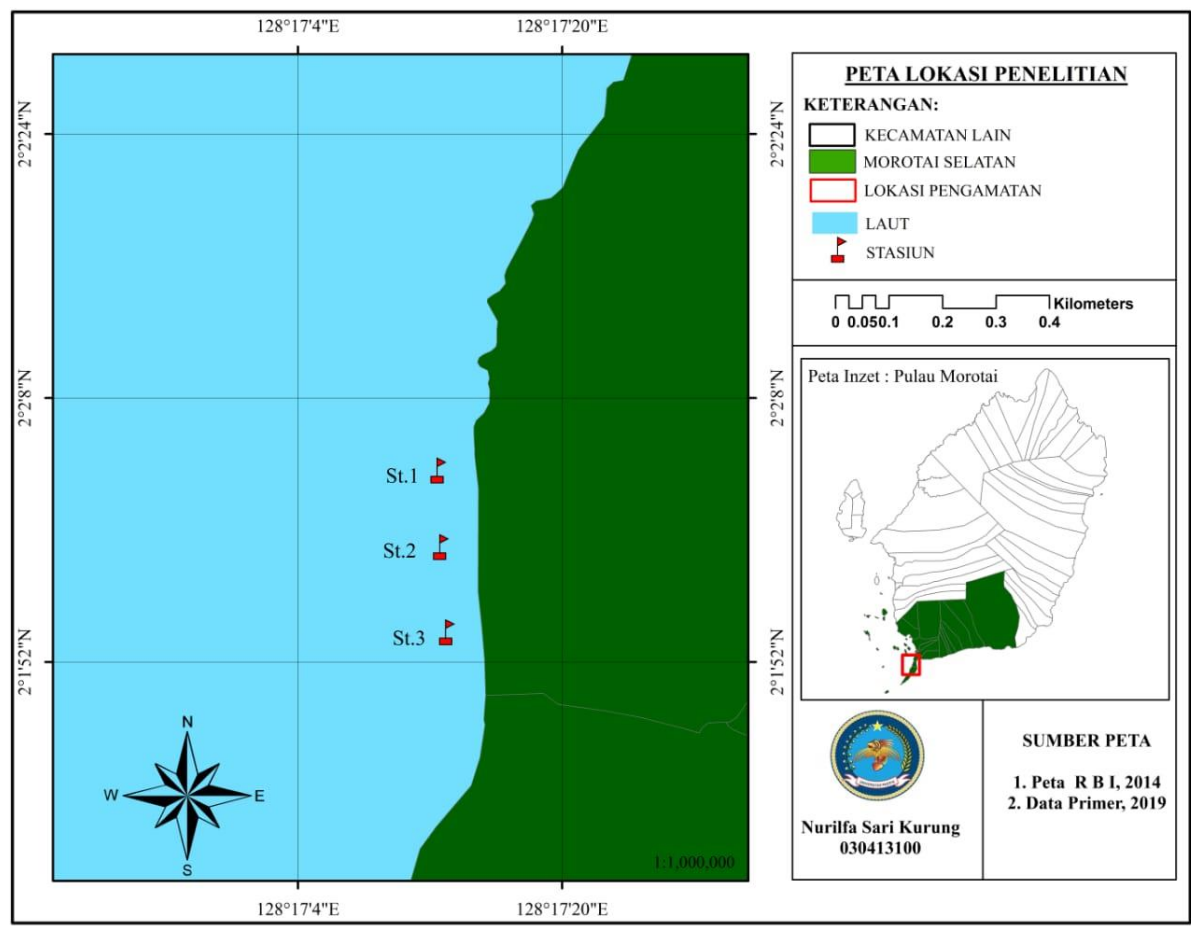

Gambar 1. Peta Lokasi Penelitian

Alat yang di gunakan dalam pengambilan data adalah Meter Roll, kuadrat 1x1, GPS (Global Position System), kayu patok transet, mistar penggaris, Hand Refraktometer, kertas lakmus, termometer, Handpone, kantong plastik dan bahan yang digunakan adalah sampel teripang. Penelitian ini menggunakan metode transek kuadrat dengan ukuran $1 \times 1$ meter yang di pasang secara tegak lurus garis pantai sampai sejauh 50 meter pada saat air laut surut terendah atau mejelang surut terendah, pada setiap transek berjarak 10 meter sedangkan jarak kuadrat $15 \mathrm{~m}$. Sampel diambil dengan menelusuri perairan Army Dock pada saat air laut surut, teripang yang ditemukan kemudian di masukan kedalam plastik sampel yang telah diberi label sesuai stasiun dan dihitung jumlah jenis dari masing masing teripang, selain itu juga dilakukan koleksi bebas kemudian di identifikasi dengan menggunakan buku panduan (Patric et al., 1995 dan Direktorat Konservasi Keanekaragaman Hayati Laut 2015). Bersamaan dengan waktu pengambilan sampel teripang dilakukan pula pengukuran beberapa parameter fisik kimia perairan diantaranya suhu, salinitas, $\mathrm{pH}$ dan substrat. Analisis data mengunakan formula kepadatan, keanekaragaman jenis, indek dominasi, kemerataan dan pola sebaran.

\section{Hasil dan Pembahasan}

Jenis teripang yang ditemukan di lokasi penelitian terdapat 4 jenis dengan jumlah 30 individu. Jenis teripang yang banyak di temukan di perairan Army Dock adalah jenis teripang Actinopyaga 
miliaris yang di temukan pada lokasi substrat berpasir dan paling terendah adalah jenis teripang Stichopus variegatus.

Tabel 1. Jenis Teripang Yang Ditemukan Di Lokasi Penelitian

\begin{tabular}{clccc}
\hline No & Jenis Teripang & \multicolumn{2}{c}{ Stasiun } & \\
& & I & II & III \\
\hline 1 & Stichopus variegatus & $\sqrt{ }$ & - & - \\
2 & Actinopyga miliaaris & $\sqrt{ }$ & $\sqrt{ }$ & $\sqrt{ }$ \\
3 & Holothuria scabra & $\sqrt{ }$ & $\sqrt{ }$ & $\sqrt{ }$ \\
4 & Holothuria rigida & $\sqrt{ }$ & $\sqrt{ }$ & - \\
\hline
\end{tabular}

Hasil identifikasi jenis teripang memiliki corak yang berbeda, ada yang bercorak hitam, hitam berbintik putih, warna kuning kecoklatan dan abu abu hitam. Jenis teripang Stichopus variegates memiliki ukuran yang lebih besar dibandingkan jenis teripang lainnya.Warna teripang Stichopus variegatus kuning kecoklatan dengan warna corak yang tidak beraturan karen terdapat sedikit corak berwarna orange. Permukaan kulit lebih halus dan bintik bintik kecil, beruas ruas membentuk lipatan. Menurut Pratiwi (2011), rata rata ukuran panjang tubuh teripang pada jenis Stichopus variegartus di perairan umumnya $\pm 20 \mathrm{~cm}$ dengan bagian dorsal berwarna coklat gelap dengan bintik berwarna coklat muda. Aziz dan Darsono (2005), menyatakan bahwa teripang suku Holothuroidea dan Stichopodidae dapat berdaptasi dan menempati segala macam tipe dasar (substrat) seperti lumpur, lumpur berpasir, pantai berbatu, karang mati dan patahan karang (rubbles).

\subsection{Parameter Kualitas Perairan}

Hasil pengukuran parameter perairan meliputi, suhu, salinitas, pH air, kedalaman, substrat, pengambilan sampel parameter di lakukan pada tiga titik dalam tiap stasiun, yaitu stasiun satu, dua, tiga. Kualitas perairan dapat memberikan pengaruh terhadap kelangsungan hidup biota laut (Tanjung et al., 2019) serta dapat menjadi faktor pembatas distribusi biota laut (Nontji, 2005).

Tabel 2. Hasil Pengukuran Parameter Kualitas Perairan

\begin{tabular}{lccc}
\hline \multirow{2}{*}{ Parameter } & \multicolumn{3}{c}{ Stasiun } \\
\cline { 2 - 4 } & I & II & III \\
\hline Suhu $\left({ }^{\circ} \mathrm{C}\right)$ & 27 & 27 & 27 \\
Salinitas $(\%)$ & 33 & 33 & 33 \\
$\mathrm{pH}$ air & 7 & 7 & 8 \\
Kedalaman $(\mathrm{m})$ & $\leq 1$ & $\leq 1$ & $\leq 1$ \\
Substrat & Berpasir & Pasir berlumpur & Berpasir \\
\hline
\end{tabular}

Hasil pengukuran suhu di lokasi penelitian stasiun I sampai III berkisar $33^{\circ} \mathrm{C}$. Salinitas yang di peroleh pada setiap stasiun di perairan Army dock memiliki nilai yang sama yaitu $33 \%$. Pengukuran $\mathrm{pH}$ air memiliki ilai pH 7-8, menurut Hasniar et al. (2011), yang menyatakan bahwa sebagian besar teripang dapat hidup pada perairan dengan $\mathrm{pH}$ berkisar 5-7. Jika di bandingkan dengan buku mutu menurut KEPMEN-LH Nomor 51 tahun 2004, nilai pH di peraian Army dock sesuai standar baku mutu yaitu berkisar 7-8,5. Untuk hasil pengukuran kedalaman di peroleh pada setiap statiun dengan rata-rata kedalaman kurang lebih $1 \mathrm{~m}$ karena pengambilan sampel dilakukan pada saat surut. Jenis substrat yang terdapat di lokasi penelitian di dominasi oleh pasir, dan pasir berlumpur. Substrat pada stasiun penelitian merupakan substrat yang baik untuk jenis teripang. 


\subsection{Kepadatan Jenis Teripang}

Kepadatan jenis pada masing masing stasiun (Gambar 2) menunjukan bahwa tingkat kepadatan jenis teripang tertinggi terdapat pada jenis Actynopyga miliaris $\left(0,14 \mathrm{ind} / \mathrm{m}^{2}\right)$, terendah Stichopus variegatus dan Holothuria rigida $\left(0,01 \mathrm{ind} / \mathrm{m}^{2}\right)$ pada stasiun I. Pada stasiun II jenis tertinggi Actynopyga miliaris $\left(0.06 \mathrm{ind} / \mathrm{m}^{2}\right)$ dan terendah Holothuria scabra $\left(0.01 \mathrm{ind} / \mathrm{m}^{2}\right.$ Sedangkan pada stasiun III kepadatan jenis tertinggi Actynopyga miliaris $\left(0,06 \mathrm{ind} / \mathrm{m}^{2}\right)$ dan terendah Holothuria scabra $(0.04$ ind $/ \mathrm{m}^{2}$ ). Kepadatan teripang juga sangat berkaitan dengan tipe substrat perairan (Handayani et al., 2017).

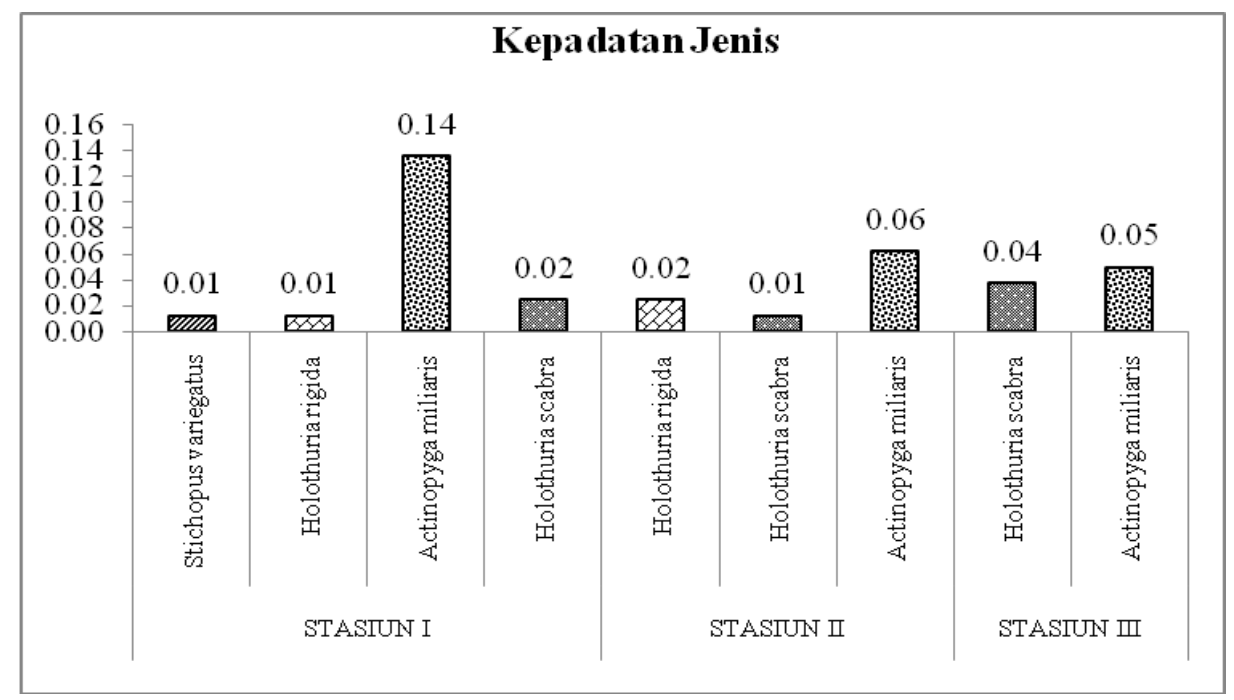

\section{Gambar 2. Kepadatan Jenis Teripang}

Kompetisi komunitas organisme senantiasa bervariasi dari satu tempat ke tempat lainnya. Tingginya kepadatan teripang pada stasiun I (satu) disebabkan oleh beberapa faktor, diantaranya pengaruh suhu, salinitas, dan $\mathrm{pH}$ yang optimum untuk organisme tersebut dapat hidup dan berkembang (Tabel 2). Selain itu habitat hidup yang sesuai dapat membuat organisme teripang memperoleh makanan sekaligus bersembunyi terhadap predatornya (Yuniarti, 2012). Habitat karang ataupun pecahan karang dapat digunakan teripang sebagai tempat perlindungan sekaligus mencari makan yang potensial. Faktor-faktor tersebut tidak di temukan pada dua stasiun lainnya (stasiun II dan III) . Sutaman (2010), menyebutkan bahwa selain dari pasir bercampur rumput laut, pecahan karang atau daerah dekat karang digunakan juga sebagai tempat persembunyian teripang. Banyak jenis teripang menyukai tipe substrat berpasir seperti jenis-jenis teripang yang ditemukan pada stasiun I dan pemilihan substrat sesuai dengan kebiasaan makan. Levinton (2005), menyatakan bahwa pemilihan substrat senantiasa disesuaikan dengan kebiasaan individu untuk mencari makan. Selain faktor ekologis, faktor sosial juga turut berperan terhadap kepadatan teripang. Lokasi penelitian di stasiun II dan III mendapat banyak tekanan dari masyarakat setempat yang mengambil teripang untuk dijual. Pengambilan yang tidak ramah lingkungan dapat merusak ekosistem teripang sekaligus mengurangi jumlah teripang di alam.

\subsection{Indeks Ekologi Teripang}

Indeks ekologi digunakan untuk perhitungan nilai keanekaragaman, kemerataan dan dominasi. Hasil perhitungan nilai keanekaragaman jenis yang paling tertinggi jenis teripang Actinopyga miliaris dengan nilai keanekaragaman $0,68-0,90$. Keanekaragaman jenis teripang di lokasi penelitian sangat bergantung pada jumlah jenis teripang dan jumlah individu yang ditemukan. Selain itu, menurut Pole (1974) dalam Suprapti (1993), bahwa keanekaragaman biota tertentu di suatu lokasi tidak hanya dilihat dari banyaknya jenis tetapi juga dari penyebaran individu dalam tiap jenisnya dan tergantung dari kelimpahan individu dalam jenis. Rendahnya nilai kenakeragaman sejalan dengan pendapat Shannon- 
Wienner (1949), bahwa indeks keanekaragaman jenis $H^{\prime}<1$ menunjukkan bahwa indeks keanekaragaman teripang pada setiap stasiun masuk dalam kategori rendah. Wa uni et al., (2016) mengemukakan bahwa indeks keanekaragaman organisme pada suatu komunitas sangat ditentukan oleh banyaknya jenis dan jumlah individu jenis. Menurut Hymann (1995), faktor faktor lain yan mempengaruhi tinggi rendahnya keanekaragaman jenis diantaranya adalah faktor persaingan antar spesies dan predator serta dari faktor manusia yaitu tangkapan nelayan. Spesies yang mempunyai kemampuan untuk mempertahankan diri maka akan mendapatkan kesempatan untuk tetap hidup dan bertahan pada habitatnya. Demikian juga pada jenis yang merupakan kategori rendah dan bukan merupakan jenis target, maka akan mendapatkan kesempatan untuk tetap hidup pada habitatnya.

Tabel 3. Hasil Analisis Indeks Ekologi

\begin{tabular}{cccc} 
Stasiun & H' $^{\prime}$ & C & E \\
\hline I & 0,86 & 0,564 & 0,618 \\
II & 0,90 & 0,469 & 0,819 \\
III & 0,68 & 0,510 & 0,985 \\
\hline
\end{tabular}

Nilai indeks kemerataan pada tiga stasiun penelitian termasuk pada kategori penyebaran jenis lebih merata dan sangat merata dengan nilai 0,618 -0,985. Sebaran organisme yang seragam atau merata dapat terjadi kalau persaingan diantara individu sangat keras sehingga akan mendorong pembagian ruang, walaupun ada beberapa spesies yang lebih dominan dari spesies yang lain. Nilai indeks dominasi $0,469-0.564$ dan paling terendah pada stasiun II. Pada stasiun I $(0,564)$ dan III $(0,510)$ memiliki nilai dominansi $>0,5$ menunjukkan bahwa adanya spesies yang mendominasi di lokasi ini. Hal tersebut mengandung arti ada kompetisi antar jenis teripang di kedua titik lokasi penelitian. Adanya ketersediaan makanan yang cukup dan kondisi lingkungan yang mendukung diduga sebagai alasan tinggi rendahnya kompetisi baik itu ruang maupun makanan.

\subsection{Pola Sebaran Teripang}

Penyebaran setiap jenis teripang pada stasiun I sampai III penyebaran yang bersifat mengelompok (Tabel 4). Hal ini menunjukkan bahwa secara umum semua jenis teripang yang ditemukan dapat beradaptasi dengan baik terhadap kondisi lingkungan perairan pada habitatnya masing-masing. Hal ini diperkuat dengan hasil pengukuran parameter fisika-kimia perairan yang masih berada pada kisaran normal bagi kehidupan teripang (Tabel 2). Penyebaran antar stasiun disebabkan adanya faktor lingkungan yang berpengaruh pada stasiun penelitian. Pola penyebaran ini banyak diakibatkan oleh rendahnya populasi setiap spesies dan adanya persaingan positif antar spesies.

Tabel 4. Pola Sebaran Teripang di Lokasi Penelitian

\begin{tabular}{cccccc} 
Stasiun & $\mathbf{X i}$ & $\mathbf{X i}^{2}$ & $\mathbf{N}$ & $\mathbf{I d}=\mathbf{n}^{*}\left(\sum \mathbf{X i}^{2}\right)-\left(\sum \mathbf{X i}\right) /\left(\sum \mathbf{X i}\right)^{2}-\left(\sum \mathbf{X i}\right)$ & Pola sebaran \\
\hline $\mathrm{I}$ & 15 & 127 & 9 & 4.8 & Mengelompok \\
II & 8 & 30 & 9 & 3.5 & Mengelompok \\
III & 7 & 25 & 9 & 3.9 & Mengelompok \\
\hline
\end{tabular}

Umumnya pola penyebaran teripang dipengaruhi oleh kondisi lingkungan yang berhubungan dengan daya adaptasi. Ketersediaan makanan dan perlindungan terhadap pengaruh predator maupun arus dan gelombang. Menurut Nirwana et al. (2016), sebaran oranisme yang seragaman atau merata dapat etrjadi kalau persaingan diantara individu sangat keras sehingga akan mendorong pembaian ruang walaupun ada beberapa spesies yan lebih dominan dari spesies yang lain. Mengelompoknya teripang diduga bahwa teripang ini disebabkan adanya parameter lingkungan tertentu sehingga jenis jenis teripang ini akan berada pada kondisi yang baik sesuai denan tingkat adaptasinya. Selain itu pola penyebaran mengelompok disebabkan pula oleh adanya hewan lain sebagai predator. Hal ini didukung 
leh martoyo et al. (2007), bahwa teripang ditemukan hidup menelompok yang bertujuan untuk saling melindungi. Hartomas (2000), mengemukakan bahwa distribusi yang bersifat mengelompk berkaitan denan distribusi habitat serta hewan hewan lainnya. Selain itu makanan merupakan faktor yang menentukan populasi, pertumbuhan dan kondisi oranisme di suatu perairan (Sarmawati et al., 2016).

\section{Kesimpulan}

Kesimpulan yang didapat dari hasil penelitian adalah analisis keanekaragaman jenis menunjukkan kategori rendah dengan nilai $\mathrm{H}^{\prime}>1$, adanya spesies yan mendominasi di stasiun I dan III dan penyebaran jenis tidak merata dari ketiga stasiun penelitian. Untuk hasil perhitungan pola sebaran menunjukkan bahwa ketiga stasiun memiliki pola sebaran mengelompok.

\section{Daftar Pustaka}

Aziz. (1997). Beberapa Catatan Tentang Perikanan Teripang Indonesia dan Kawasan Indo Pasifik Barat, Oseana 2:68-78.

Aziz \& Darsono. (2005). Beberapa Catatan Mengenai Fauna Ekhinodermata di Daerah Rataan Terumbu Karang Bagian Selatan Gugus Pulau Pari, Pulau-Pulau Seribu, Balitbang Biologi, Puslitbang Oseanologi LIPI, Jakarta

Direktorat Konservasi dan Keanekaragamn Hayati Laut. (2015). Pedoman Identifikasi dan Monitoring Populasi Teripang. Kementerian Kelautan dan Perikanan. ISBN: 978-602-7913-2-0

Hasniar, M., Litaay, \& Priosambodo, D. (2011). Biodiversitas Gastropoda di Padang Lamun Perairan Mara' bombang Kabupaten Pinrang Provinsi Sulawesi Selatan. Torani, 23 (3) : 127 - 136.

Hartomas, K. (2000). Beberapa parameter Fisika dan Kimia Perairan yang Mempengaruhi Kelimpahan dan Distribusi Berbagai Jenis Teripang Holothuria scabra pada Habitat Pasir Berlumpur dan Lamun di Perairan Teluk Kulisusu kabupaten Muna. Skripsi. Jurusan Perikanan. Fakultas Pertanian. Univeritas Haluloeo. Kendari.

Hymann LH. (1995). The Invertebrates Echinodermata, the Coelomate Bilateria. Vol. IV. Mc Graw Hill Book Co. New York: 224p

Handayani, T., Sabariah, V., dan Hambuako, R.R. 2017. Komposisi spesies teripang (Holothuroidea) di perairan kampung Kapisawar Distrik Meos Manswar Kabupaten Raja Ampat. Jurnal perikanan Universitas Gadjah Mada, 19 (1), 45-51.

Kementerian Negara Lingkungan Hidup. 2004. Keputusan Menteri Negara Lingkungan Hidup Nomor 51 Tahun 2004 Tentang Baku Mutu Air Laut.

Levinton, J.S. (2005). Marine Ecology. Prentice hall, Inc, Englewood cliffs, New Jersey.

Martoyo, J., Aji, N., \& Winanto, T. (2007). Budidaya Teripang. Penebar Swadaya. Jakarta. 76 hal

Nirwana, E., Sadarun, B., \& Afu. (2016). Studi Struktur Komunitas Teripang Berdasarkan Kondisi Substrat di Perairan Desa Sawapudo Kabupaten Kunawe. Sapa Laut. Vol 1 (1): 17-23

Nontji A. (2005). Laut Nusantara. Djambatan. Jakarta

Pratiwi, F. (2011). Identifikasi Jenis jenis Holothuroidea (Echinodermata) di Rataan Terumbu Beberapa Pulau Taman Nasional Kepulauan Seribu Jakarta. Skripsi. Fakultas Matematika dan IImu Pengetahuan Alam. Universitas Indonesia. Depok

Sarmawati, Ramli, M., \& Ira. (2016). Distribusi dan Kepadatan Teripang (Holothuridea) di Perairan Tanjung Tiram Kecamatan Moramo Utara Kabupaten Konawe Selatan. Jurnal Manajemen Sumber Daya Perairan, 1(2): 183-194

Sutaman. (2010). Petunjuk Praktis Budidaya Teripang. Kanisius. Jakarta.

Shannon, C.E, \& Wienner, W. (1949). The Mathematical theory of Communication. University of Illionis Press. Urbanan

Suparti, N. H. Sugondo, M. dan U. Tarwodjo. 1993. Studi plankton disekitar Daerah PLTU. Semarang. $7 \mathrm{hlm}$ 
Tanjung, R.H.R., Hamuna, B., \& Alianto. (2019). Asessment of Water quality and pollution index in coastal waters of Mimika, Indonesia. Journal of Ecological Engineering, 20 (2), 87-94

Wa uni, Ramli, M., \& Ishak, E. (2016). Keanekaragaman dan kepadatan teripang di perairan Tanjung Tiram Kecamatan Moramo Utara Kabupaten Konawe Selatan. Jurnal Manajemen Sumber Daya Perairan, 1(2): 201-211

Yuniarti, N. (2012). Keanekaragaman dan Distribusi Bivalvia dan Gastropoda (Moluska) di Pesisir Glayem Juntinyuat, Indramayu, Jawa Barat. Skripsi. Departemen Biologi Fakultas Matematika Dan IImu Pengetahuan Alam. Institut Pertanian Bogor. Bogor. 
